DOI 10.4467/2543733XSSB.20.001.12198

TADEUSZ CZEKALSKI

Uniwersytet Jagielloński

\title{
EKSPOZYCJE BUNK'ART W TIRANIE W KONTEKŚCIE ALBAŃSKIEJ POLITYKI PAMIĘCI
}

\section{Bunk'Art Exhibitions in Tirana in the Context of Albanian Politics of Memory}

Summary

The text examines how the Bunk'Art 1 and Bunk'Art 2 exhibitions, opened in 2014-2016 in Tirana fit in the main narrative trends of the Albanian memory of the communist past. The project of the Italian journalist Carlo Bollino has become one of the key elements of the new policy of socialist memory of the government of Edi Rama, and at the same time an attempt to create modern cultural institutions in the old atomic bunkers from the time of Enver Hoxha, in which history becomes a space dominated by artists and journalists, and at the same time competitive towards professional historians.

Key words: Albania, Bunk'Art, museum of communism, politics of memory

Słowa kluczowe: Albania, Bunk’Art, muzeum komunizmu, polityka pamięci

W pracy poświęconej współczesnym instytucjom muzealnym w krajach europejskich węgierski historyk Péter Apor zwraca uwagę na szczególną rolę, jaką we wschodniej i południowo-wschodniej części kontynentu odgrywają instytucje określane mianem „muzeów komunizmu". Apor przyznaje im kluczowe znaczenie w budowaniu narracji wiktymistycznej, sprzyjającej postrzeganiu społeczeństw Europy Środkowo-Wschodniej jako ofiar dwudziestowiecznych systemów totalitarnych, narzuconych siłą przez czynniki zewnętrzne ${ }^{1}$. Przekaz typowego muzeum komunizmu zostaje skierowany w stronę młodego pokolenia, ale także przybyszy spoza Żelaznej Kurtyny, którzy nie zetknęli się z komunizmem jako doświadczeniem osobistym. Potencjalną atrakcyjność takich obiektów dla tu-

${ }^{1}$ P. Apor, Museums of cilivization, museums of state, museums of identity; national museums in Europe, 1918-2000, [w:] National Museums and Nation-Bulding in Europe 1750-2010. Mobilization and Legitimacy, Continuity and Change ed. P. Aronsson i G. Elgenius, Routledge 2015, s. 55. 
rysty z Zachodu określa ekscytacja odmiennością funkcjonowania człowieka w czasach dyktatury, jakże odmiennego niż doświadczenia życiowe osób żyjących w społeczeństwach demokratycznych.

Pod wieloma względami albański reżim Envera Hodży - zestawiony z innymi państwami bloku sowieckiego - wydaje się oryginalny i niepowtarzalny. Wystarczy w tym miejscu przywołać przykład państwowego ateizmu, który w przeciwieństwie do innych krajów komunistycznych doprowadził w 1967 r. do eliminacji religii z przestrzeni publicznej i uznania aktywności religijnej za formę przestępstwa. Bez precedensu, przynajmniej na kontynencie europejskim, wydaje się trwałość modelu kultury socrealistycznej, funkcjonującego w Albanii przez ponad czterdzieści lat, jak również aplikacja modelu ,wojny ludowej”, która od lat 70. stanowiła doktrynę obronną państwa albańskiego. Do roku 1991 w Albanii nie istniała zorganizowana opozycja antykomunistyczna, represyjność reżimu nie pozwalała także na jakiekolwiek formy oporu społecznego, realizowane w wymiarze jednostkowym.

Słabością procesów dekomunizacyjnych w Albanii stał się brak ich instytucjonalizacji, a w konsekwencji brak spójnej polityki pamięci. W pierwszej dekadzie postkomunistycznej nie udało się powołać do życia instytucji, która w sposób naukowy podjęłaby kwestię badań nad przeszłością komunistyczną i zajęła się opracowaniem dokumentacji archiwalnej, w początkach lat 90. i tak w znacznej mierze zniszczonej lub rozproszonej. Koncentracja na doraźnych celach politycznych, czyli dążenie do wyeliminowania ze sceny politycznej osób obciążonych aktywnością publiczną przed 1991 r. - spowodowała, że spóźnione debaty o istocie komunizmu podjęto dopiero kilkanaście lat po jego upadku, w atmosferze emocji i sporów dotyczących poszczególnych karier politycznych, i prób powrotu do symboliki minionych czasów.

Podobnie jak w przypadku bułgarskim, analizowanym przez Dorotę Gołek-Sepetliewą, także społeczeństwo albańskie doświadczało dwóch skrajnych postaw w ocenie przeszłości komunistycznej: niedostatku pamięci i jej nadmiaru². Pierwsza z tych tendencji stała się konsekwencją niechęci do powrotu do traumatycznej przeszłości, ale także kształtowania wyrywkowej i schematycznej wizji przeszłości, wzmacnianej przez nostalgiczne produkcje filmowe z lat 70. i 80. XX w., stale obecne w albańskich mediach. Nadmiar pamięci - wyrażany poprzez ciagłe i natarczywe repetycje traumatycznej przeszłości, stał się cechą charakterystyczną ofiar systemu i ich rodzin, które nie tylko nie doświadczyły zadośćuczynienia w stopniu ich zadowalającym, ale także spotykają się z przejawami obojętności, a ich poświęcenie i ofiary, które ponieśli, są zapomniane.

Natężenie sporów o historię, rozgrywających się w pierwszej dekadzie postkomunistycznej, zostało skojarzone z postulatami rozrachunkowymi w kategoriach prawno-politycznych, ale także z poszukiwaniem nowych sposobów opowiadania o niedawnej przeszłości. Poszczególne grupy konstruowały własne narracje odnoszące się do komunistycznej przeszłości. Oprócz oficjalnej urzędowej polityki pamięci zaczęły się rozwijać także „niepaństwowe” (prywatne) inicjatywy upamiętniania minionej epoki. Kształtowanie prywatnych strategii komemoratywnych należy przypisywać środowisku byłych więźniów

${ }^{2}$ D. Gołek-Sepetliewa, Dychotomia pamięci w postkomunistycznej Bułgarii, „Acta Baltico-Slavica” 42: 2018, s. 28; A. Grgic, Deviating memories: Armando Lulaj's seriously playful excursions into Albania s history, „Images” vol. XXIII, nr. 32 (2018), s. 50. 
systemu, ale także duchownym, szczególnie przedstawicielom Kościoła katolickiego, którzy podjęli próbę uświadomienia społeczeństwu konsekwencji polityki ateizacyjnej. Deprofesjonalizacji dyskusji o komunizmie sprzyjało charakterystyczne dla krajów bałkańskich niewielkie zainteresowanie zawodowych historyków badaniem tej epoki. Jak pisze Ulf Brunnbauer, badania historyczne stosunkowo rzadko przekraczały granicę końca lat 40. XX wieku. Niechęć do podejmowania badań nad komunizmem niemiecki historyk thumaczy ograniczonym dostępem do bazy źródłowej, obawami o upolitycznienie tych badań, co utrudniało uzyskanie obiektywnej oceny przeszłości, a nierzadko także świadomością dyskredytujących badacza powiązań z systemem komunistycznym ${ }^{3}$. W prasie codziennej temat komunizmu stosunkowo coraz częściej podlega tabloidyzacji. Odwołanie do najbardziej tragicznych wydarzeń z lat 1944-1991 poprzez incydentalne relacje czy dokumenty staje się równie powszechne, jak przeprowadzanie wywiadów z bohaterami czasów minionych, których opowieści skłaniają się ku kształtowaniu idyllicznej wizji przeszłości.

\section{Narracja urzędowa}

Symbolicznym początkiem procesu rozliczania przeszłości komunistycznej w Albanii stało się objęcie władzy przez Demokratyczną Partię Albanii (DPA), po zwycięskich dla niej wyborach w marcu 1992 roku. Największa partia opozycyjna przejmowała władzę pod hasłem rozliczeń i czystek personalnych, zmierzających do eliminacji z przestrzeni publicznej osób związanych z reżimem komunistycznym. Wybór strategii radykalnej dekomunizacji sprzyjał budowie twardego elektoratu, który miało tworzyć środowisko osób politycznie represjonowanych, a także członków ich rodzin ${ }^{4}$.

Symbolem rozliczeń z komunizmem w okresie rządów demokratów stały się dwie ustawy z 1995 r., które ukształtowały model albańskiej lustracji. Pierwsza z nich - Ustawa o ludobójstwie, uchwalona 22 września 1995 r., zakładała eliminację z funkcji publicznych osób, które działały na stanowiskach kierowniczych państwa komunistycznego, a także we władzach Albańskiej Partii Pracy5 . Dwa miesiące później, 30 listopada 1995 r., zdominowany przez deputowanych Demokratycznej Partii Albanii parlament uchwalił ustawę weryfikacyjną, ${ }^{6}$ uniemożliwiająca pełnienie funkcji ważnych z punktu widzenia bezpieczeństwa państwa wszystkim byłym współpracownikom komunistycznych służb specjalnych. Zastosowanie w praktyce politycznej ustawy z 1995 r. pozwoliło na eliminację po-

${ }^{3}$ U. Brunnbauer, Introduction, [w:] (Re)Writing History: Historiography in Southeast Europe after Socialism, ed. Idem, Münster 2004, s. 25.

${ }^{4}$ F. C. Abrahams, Modern Albania. From Dictatorship to Democracy in Europe, New York \& London 2015, s. 96.

${ }^{5}$ Pełna nazwa dokumentu: Ustawa o ludobójstwie i zbrodniach przeciwko ludzkości popełnionych w Albanii w czasie rządów komunistycznych z motywów politycznych, ideologicznych i religijnych (ustawa 8001) http:/www.ikub.al/LIGJE/509220003/Article-Per-genocidin-dhe-kerkimin-kunder-njerezimit-kryer-ne-Shqiperigjate-sundimit-komunist-per-motive-politike-ideologjike-dhe-fetare.aspx?cookie (data dost. 2 marca 2019 r.).

${ }^{6}$ Pełna nazwa dokumentu: Ustawa o weryfikacji postaw etycznych urzędników i innych osób związanych z obroną państwa demokratycznego - http:/www.ikub.al/LIGJE/801150003/Article-Per-disa-ndryshime-ne-ligjinnr-8043-date-30-11-1995-Per-kontrollin-e-figures-se-zyrtareve-dhe-personave-te-tjere-qe-lidhen-me-mbrojtjene-shtetit-demokratik-ndryshuar-me-ligjin-nr-8151-date-12-09-199.aspx (data dost. 2 marca 2019 r.). 
lityczną większości członków władz postkomunistycznej Socjalistycznej Partii Albanii, a także jednej czwartej deputowanych do parlamentu? ${ }^{7}$.

Demokratyczna Partia Albanii, która patronowała kształtowaniu prawicowej narracji antykomunistycznej, już w pierwszym okresie swoich rządów przestała być formacją jednolitą politycznie, nie była też w stanie wytworzyć spójnego modelu pamięci. Po objęciu steru rządów przez partię socjalistyczną w 1997 r. na forum publiczne powróciły osoby dyskredytowane w poprzednich latach, a historia komunizmu trafiła do kategorii tematów drugorzędnych, które nie budziły już takiego zainteresowania ani emocji jak w pierwszych latach transformacji ustrojowej. Kojarzenie upadku piramid finansowych wiosną $1997 \mathrm{r}$. z radykalizmem politycznym DPA stało się dogodnym uzasadnieniem porzucenia praktyki rozliczeń za zbrodnie komunistyczne i zawieszenia procedur lustracyjnych.

Powrót Demokratycznej Partii Albanii do władzy po zwycięskich wyborach 2005 r. nie oznaczał co prawda przywrócenia radykalizmu lustracyjnego z lat 90., ale koncentrację na konfrontacji ideologicznej, w której zwycięska partia występowała jako rzecznik mentalnej i świadomościowej dekomunizacji społeczeństwa albańskiego ${ }^{8}$. Kluczową rolę w tych planach odgrywała nowa polityka historyczna, odwołująca się do hasła rishikimi i historise (rewizja historii). Projekt rewizji historii koncentrował się na ukazaniu społeczeństwa albańskiego jako ofiary systemu, a także eksponowaniu wszelkich form oporu przeciwko systemowi. Klasyczny przykład tego typu działań stanowiło nadmierne eksponowanie w narracji o przeszłości wątku powstania postrybskiego (9 września 1946 r.), traktowanego jako pierwsze w dziejach Europy powstanie antykomunistyczne. Kontynuację rewizjonistycznych haseł „polityki historycznej” rządzącej partii można odnaleźć w jednej z ,programowych” wypowiedzi Salego Berishy, który w 2010 r. domagał się jednoznacznego potępienia przez historyków postaci Envera Hodży, tak aby miejsce nostalgii za okresem jego rządów zajęła świadomość zbrodni, których dopuścił się wówczas reżim9.

Pomysł na utworzenie muzeum pamięci narodowej na terenie dawnego obozu pracy w Spaçu wydawał się chybiony już w momencie powstania. Zrujnowane budynki dawnego obozu otaczają bowiem tereny rudonośne, a plany, by wznowić wydobycie rud pirytu, postawiły pod znakiem zapytania możliwość uruchomienia w tym miejscu obiektu muzealnego $^{10}$. W tym czasie rozpatrywano także dwie inne możliwe lokalizacje dla tego projektu: więzienie w Burrelu lub dom Envera Hodży w Gjirokastrze. Funkcji muzealnych nie mogło jednak pełnić więzienie w Burrelu, które nadal wykorzystywano do celów peniten-

\footnotetext{
${ }^{7}$ Podstawą instytucjonalną albańskiej lustracji miała stać się sześcioosobowa komisja ds. weryfikacji dokumentów tajnej policji, kierowana przez przewodniczącego powoływanego przez parlament - R. C. Austin, Transitional Justice as Electoral Politics, [w:] Post-Communist Transitional Justice. Lessons from Twenty-Five Years of Experience, ed. Lavinia Stan, Nadya Nedelsky, Cambridge University Press 2015, s. 34-36.

${ }^{8}$ Nieudaną próbą powrotu do ustawodawstwa lustracyjnego był projekt ustawy 10/034/2008 ,O przejrzystości wysokich funkcjonariuszy administracji publicznej i osób zajmujących stanowiska z wyboru”, który w art. 4 jednoznacznie nawiązywał do ustawy z listopada 1995 r. W marcu 2010 r. Sąd Konstytucyjny Albanii uznał ustawę za niezgodną z obowiązującą w Albanii ustawą zasadniczą - A. Elbasani i A. Lipiński, Transitional Justice in Albania: Historical Burden, Weak Civil Society and Conflicting Interests, [w:] Transitional Justice and Civil Society in the Balkans, ed. O. Simić, Z. Volčič, New York 2013, s. 116-117.

9 T. Czekalski, (Nie)pamięć o komunizmie. Przypadek albański, ,Rocznik Antropologii Historii” 2012, nr $1-2$, s. 166.

${ }^{10} \mathrm{~W}$ maju 2018 r., w 25. rocznicę buntu osadzonych w Spaçu, stowarzyszenie skupiające byłych więźniów obozu podjęło inicjatywę zmierzającą do uruchomienia w tym miejscu stałej przestrzeni ekspozycyjnej - zob. http://www.spacimuseum.org [data dost. 3 marca 2019].
} 
cjarnych. Dom rodzinny Envera Hodży w Gjirokastrze, który już w 1967 r. zamieniono w muzeum etnograficzne, zachował swój pierwotny charakter także w okresie postkomunistycznym. Widoczny spadek zainteresowania epoką komunistyczną wśród historyków i publicystów nastąpił wraz z intensyfikacją przygotowań do obchodzonego w 2012 r. jubileuszu 100-lecia państwa albańskiego.

Zwycięstwo Socjalistycznej Partii Albanii (SPA) Ediego Ramy w wyborach parlamentarnych 2013 r. nie przyniosło początkowo zasadniczych zmian w polityce historycznej władz albańskich. Ukształtowany w latach 90. lewicowy dyskurs o komunizmie, kojarzony z Socjalistyczną Partią Albanii, wpisywał się w postawę utopijno-etyczną ${ }^{11}$. Ujawnianie prawdy o przeszłości w tym przypadku miało nie zagrażać idei konsolidacji narodu i budowy wspólnej tożsamości. Z tej perspektywy dyskurs o komunizmie koncentrował się na przedstawianiu społeczeństwa albańskiego jako ofiary systemu i eksponowaniu incydentalnych postaw społecznego oporu, przy braku jakiejkolwiek refleksji nad odpowiedzialnością jednostek i środowisk za zbrodnie. Niepopularne, bo kojarzone z DPA hasło rewizji historii zostało z czasem zastapione postulatem ,przepisania historii na nowo” (ri-shkrimi e historise). Zasady polityki historycznej SPA określiła w listopadzie 2014 r. minister edukacji Lindita Nikolla, otwierając obrady konferencji poświęconej 70. rocznicy wyzwolenia Albanii spod okupacji niemieckiej. Zwracając się do zebranych, Nikolla podkreśliła wagę, którą przywiązuje jej rząd do konieczności napisania nowych podręczników historii dla albańskich uczniów i studentów, ,wolnych od ducha konfrontacji i nienawiści, a także zgodnych ze standardami europejskimi”. Minister edukacji zaznaczyła także, że „pisanie historii należy pozostawić wyłącznie historykom i nikomu innemu, a jej rząd nie ma na to żadnego wpływu'" ${ }^{12}$.

Stopniowo odwołanie do historii w strategii politycznej SPA zyskiwało na znaczeniu, stając się jednym z kluczowych elementów strategii integracyjnej bałkańskiego kraju, który poprzez historię miał udowodnić swój istotny wkład do kultury europejskiej. Polityczne zaplecze partii Ediego Ramy, postrzeganej nadal jako partia postkomunistyczna, nie skłaniało do podjęcia kontrowersyjnych tematów związanych z epoką Envera Hodży, koncentrując się na XV-wiecznym dziedzictwie państwa Skanderbega, walczącego skutecznie przeciwko osmańskiej dominacji. Punktem kulminacyjnym dla tego tematu stały się obchody Roku Skanderbega w roku 2018, pozwalające na przypomnienie jego postaci, która idealnie wpisywała się w scenariusz definiowania Albanii jako aktywnego uczestnika obrony chrześcijańskiej Europy przed inwazją islamu.

\section{Narracja heroiczno-wiktymistyczna}

Do roli najważniejszego ośrodka naukowego w Albanii podejmującego kwestię rozliczenia z epoką komunistyczną awansował działający od 2010 r. Instytut Badań nad Zbrodniami i Konsekwencjami Komunizmu (Instituti i Studimeve per Krimet dhe Pasojat e Komunizmit, ISKK), kierowany przez Agrona Tufę. Kluczowym projektem realizowanym

\footnotetext{
${ }^{11}$ D. Gołek-Sepetliewa, op. cit., s. 26-27.

${ }^{12}$ Pełny tekst przemówienia zob. Konferenca Shkencore për 70-Vjetorin e Çlirimit, https://arsimi.gov.al/ konferencja-shkencore-per-70-vjetorin-e-clirimit/ [data dost. 5 marca 2019].
} 
przez Instytut stało się badanie zbrodni komunistycznych popełnionych w Albanii w latach 1941-1990 i gromadzenie dokumentacji dotyczącej ofiar ${ }^{13}$. Proces identyfikacji ofiar reżimu miał prowadzić do ich pełnej rehabilitacji, a także odpowiedniego zadośćuczynienia za doznane krzywdy. Konsekwentne przypominanie krzywd z przeszłości staje się w planowanej misji ISKK fundamentem budowy nowego ładu społecznego. W tym kontekście kwestie rozliczenia i ukarania sprawców jawią się jako mniej istotne niż uświadomienie społeczeństwu skali dokonanych zbrodni. W zespole kierowanym przez Agrona Tufę znaleźli się dziennikarze, pisarze, prawnicy, a także przedstawiciele środowiska byłych więźniów politycznych. Nieliczna stosunkowo reprezentacja zawodowych historyków w tym zespole wpłynęła na charakter prowadzonych prac, które w wielu sytuacjach nabierają charakteru przypadkowego i pozbawionego rygorystycznych założeń metodologicznych. Aktywność medialna dyrektora Instytutu koncentrowała się na dekomunizacji Albanii w wymiarze kulturowym ${ }^{14}$.

Plonem kilku lat działalności Instytutu jest szereg publikacji poświęconych polityce represyjnej w pierwszych latach po zakończeniu II wojny światowej, aktywności antykomunistycznych oddziałów zbrojnych, a także edycje dokumentów archiwalnych, związanych z procesami politycznymi. Jednym z głównych zadań wynikających z misji Instytutu stało się opracowanie - na podstawie tych dokumentów wytworzonych przez Służbę Bezpieczeństwa (Sigurimi), które nie uległy zniszczeniu w latach 1990-1992 - bazy danych osób represjonowanych. Baza stała się podstawą do publikacji słownika ofiar komunizmu, który stanowi pierwszą poważną próbę całościowej dokumentacji skali represji.

\section{Narracja demitologizująco-upamiętniająca}

Wyjątkowe miejsce na mapie albańskiego dyskursu o komunizmie zajmuje środowisko albańskich intelektualistów, skupione wokół pisma „Përpjekja” (Wysiłek), kierowanego przez analityka i publicystę, a także byłego więźnia politycznego Fatosa Lubonję. W eseju $O$ duchu krytyki z 1995 r. Lubonja uznał konieczność demistyfikacji historii za jedno z najważniejszych zadań stojących przed elitami postkomunistycznej Albanii, zaś manipulowanie historią za niebezpieczne działanie pogłębiające alienację Albanii na arenie międzynarodowej, ale także sprzyjające pogłębianiu konfliktów wewnątrz społeczeństwa albańskiego ${ }^{15}$. Jednoznacznie krytyczny pogląd w odniesieniu do dyktatury Envera Hodży staje się w przypadku Lubonji pretekstem do ukazania pozornej dekomunizacji społeczeństwa i postępującej reprodukcji elit komunistycznych. W wywiadzie z 1995 r. Lubonja zwrócił uwagę na specyfikę systemu rządów E. Hodży i brak jasnych kryteriów oceny indywidualnej odpowiedzialności za zbrodnie komunizmu, co znacząco utrudnia kwestię

\footnotetext{
${ }^{13}$ Strona internetowa ISKK - http://www.iskk.gov.al/?page_id=1000 [data dost. 5 marca 2019].

${ }^{14} \mathrm{~W} 2017$ r. Agron Tufa przedstawił publicznie kontrowersyjną propozycję, aby zakazać emisji w albańskich mediach filmów fabularnych, które powstały w okresie rządów Envera Hodży i propagują system totalitarny Agron Tufa tregon kërcënimet: Pse duhen ndaluar filmat e komunizmit, rozm. A. Mille, „Panorama” 15 III 2017, http:// www.panorama.com.al/agron-tufa-tregon-kercenimet-pse-duhet-te-ndalohen-filmat-e-komunizmit/ [data dost. 2 marca 2019].

${ }^{15}$ F. Lubonja, O duchu krytyki, [w:] Idem, Albania - wolność zagrożona. Wybór publicystyki z lat 1991-2002, tt. D. Horodyska, Sejny 2005, s. 40-41.
} 
rozliczeń ${ }^{16}$. Cechą charakterystyczną środowiska „Përpjekji” stała się tendencja do kwestionowania prób dostosowywania oceny komunizmu do bieżących celów politycznych krytyczna w odniesieniu do polityki pamięci obu największych partii politycznych. Jedną z najważniejszych form aktywności środowiska jest koordynacja przedsięwzięć służących demitologizacji i depolityzacji historii Albanii we współpracy z międzynarodowym środowiskiem badaczy dziejów tego kraju. Postulat upamiętnienia ofiar komunizmu w postaci obiektu muzealnego w jednym z dawnych obozów pracy - wspierany przez „Përpjekję” - nie doczekał się realizacji. Trwałym śladem praktyk komemoratywnych tego środowiska stała się odsłonięta w Tiranie instalacja Postbllok, według projektu Ardiana Isufiego, sąsiadująca z Bllokiem (w czasach komunistycznych odrębną dzielnicą zamieszkałą przez elitę partyjno-polityczną) $)^{17}$.

\section{Postawy nostalgiczne}

Główny ton narracji, którą można by określić mianem nostalgicznej, ale także aktywnie broniącej cywilizacyjnego dziedzictwa komunizmu, nadają przedstawiciele pokolenia, które w latach 80 . XX w. osiagnęło szczyt kariery zawodowej i politycznej, zachowując zarazem głęboko krytyczny obraz przemian dokonujących się w Albanii w pierwszej dekadzie postkomunistycznej. Przypisywanie temu środowisku postaw pełnej identyfikacji z formacją komunistyczną nie zawsze wydaje się właściwe. Ugrupowania polityczne, które w najbardziej jednoznaczny sposób eksponowały przywiązanie do komunizmu w wersji Envera Hodży, jak Komunistyczna Partia Albanii Hysni Milloshiego, nigdy nie cieszyły się znaczącym wsparciem społecznym, co przekładało się na minimalne poparcie w kolejnych wyborach parlamentarnych. Większość nostalgików identyfikuje się raczej z środowiskami, w których poprzednio działali (choćby dawnych organizacji młodzieżowych), zaś dystansuje się od działań ugrupowań politycznych, którymi kierują dawni działacze niskiego szczebla, nieposiadający charyzmy ani rozpoznawalności.

O rosnącej aktywności pogrobowców systemu, a także ich obecności w przestrzeni publicznej, kojarzonej z rewitalizacją komunistycznej ikonosfery, prasa albańska pisała w kontekście kolejnych obchodów rocznicowych - stulecia urodzin Envera Hodży (2008 r.), rocznicy ustanowienia systemu komunistycznego (2015 r.), a także kolejnych obchodów rocznicy zorganizowania konferencji w Pezie, kluczowej w mitologii państwa komunistycznego $^{18}$. Powrotowi środowisk postkomunistycznych na scenę publiczną sprzyjała także awantura, którą rozpętał Blendi Fevziu, wydając w 2011 r. krytyczną biografię Envera Hodży, i organizowane spontanicznie w miastach Albanii akcje publicznego palenia

${ }^{16}$ F. Lubonja, O przenosinach prochów Envera Hodży, [w:] Idem, Albania - wolność zagrożona..., s. $217-218$.

${ }^{17}$ Instalacja, odsłonięta 26 marca 2013 r., składa się z trzech elementów - zachowanego z czasów komunistycznych bunkra, przeznaczonego dla albańskiej rodziny, betonowych słupów pochodzących z obozu pracy w Spaçu i fragmentu muru berlińskiego - R. Isto, The Monument as Ruin: Natality, Spectrality, and the History of the Image in the Tirana Independence Monument, ,Sic: časopis za književnost, kulturu i književno prevođenje", 2006/2, s. 22.

${ }^{18}$ Konferencja w Pezie - zorganizowana we wrześniu 1942 r. we wsi Peza, leżącej 11 km od Tirany - doprowadziła do powstania Ruchu Narodowowyzwoleńczego - jednolitej struktury kierowniczej ruchu oporu, która umożliwiła komunistom dwa lata później przejęcie władzy w Albanii. 
książki Fevziu. Wydanie biografii Hodży zbiegło się w czasie ze śmiercią ostatniego przywódcy komunistycznego Ramiza Alii (październik 2011 r.), będącej inspiracją dla debaty publicznej, w której zabierali głos dawni współpracownicy Alii, dziennikarze i publicyści. Zapomniany przez dwadzieścia lat transformacji ustrojowej pierwszy prezydent niekomunistycznej Albanii poprzez swoją śmierć awansował do rangi pioniera albańskiej demokracji i inicjatora przemian demokratycznych. Pojawienie się w albańskim dyskursie publicznym portretu Alii jako „ostatniego dyktatora i pierwszego demokraty” Fatos Lubonja postrzega jako klasyczny przykład utrzymywania się w społeczeństwie albańskim tendencji oportunistycznych i serwilistycznych. W opinii albańskiego publicysty kultura autorytarna, z której społeczeństwu nie udało się wyzwolić, skłania do zapominania o okrucieństwach systemu albo do ich usprawiedliwiania specyfiką „tamtych czasów”19.

\section{Projekt Bunk’Art}

Do 2014 r. największe ekspozycje poświęcone epoce komunizmu wystawiało Narodowe Muzeum Historyczne w Tiranie oraz stołeczna Galerii Sztuki. Ta ostatnia, w ramach ekspozycji stałej, udostępniła część bogatego zbioru obrazów i rzeźb, powstałych w latach 1944-1990, a związanych ściśle z estetyką socrealizmu. Upamiętnianiu zbrodni komunistycznych służył jeden z ośmiu pawilonów, tworzących stałą ekspozycję Narodowego Muzeum Historycznego ${ }^{20}$. Pawilon Komunistycznego Terroru prezentował niezwykłą kolekcję przedmiotów osobistych związanych z ofiarami systemu, ale także eksponował bogaty zbiór dokumentów i fotografii, zgromadzonych w archiwach komunistycznej służby bezpieczeństwa Sigurimi ${ }^{21}$.

Jedną z rozpatrywanych lokalizacji przyszłego muzeum komunizmu stał się usytuowany w centrum stolicy Dom Liści, oddany w przeszłości do dyspozycji funkcjonariuszy Sigurimi. Przedłużający się remont budynku i brak środków finansowych spowodował, że muzeum uruchomiono dopiero w 2017 r., nadając mu osobliwy charakter ,muzeum techniki operacyjnej”, wykorzystywanej w działaniach inwigilacyjnych ${ }^{22}$. Trzy lata przed otwarciem dla zwiedzających Domu Liści, w 70. rocznicę przejęcia władzy przez komunistów w Albanii z udziałem członków albańskiego rządu dokonano otwarcia ekspozycji wideo-muzealnej Bunk'Art 1, umiejscowionej wewnątrz dawnego schronu atomowego Envera Hodży (określanego kryptonimem Obiektu 0774), zbudowanego w północno-wschodniej części Tirany ${ }^{23}$.

${ }^{19}$ F. Lubonja, Ramiz Alia eshte midis nesh, „Panorama” 14 października 2011, http://www.panorama.com. al/ramiz-alia-eshte-midis-nesh/ [data dost. 2 marca 2019].

${ }^{20}$ Szerzej: K. Giakoumis, Pragmatist Politics on Memory and Oblivion. Post-Communist Attitudes towards Communist Museology in Albania, [w:] Between Apathy and Nostalgia. Public and Private Recollections of Communism in Contemporary Albania, ed. J. Godole, I. Idrizi, Tirana 2019, s. 46-59.

${ }^{21}$ Strona internetowa muzeum - http://www.mhk.gov.al/?portfolio=pavijoni-i-terrorit-komunist [data dost. 2 marca 2019].

${ }^{22}$ Strona internetowa muzeum - http://muzeugjethi.gov.al [data dost. 2 marca 2019]. Wśród instytucji muzealnych upamiętniających ofiary terroru komunistycznego godne uwagi jest także Miejsce Świadectwa i Pamięci (Vendi i Dëshmisë dhe Kujtesës) - niewielka ekspozycja o charakterze lokalnym, otwarta dla zwiedzających we wrześniu 2014 r. w dawnej siedzibie Urzędu Spraw Wewnętrznych w Szkodrze.

${ }^{23}$ Schron atomowy Envera Hodży powstawał w latach 1972-1978 - zaprojektowany jako obiekt pięciokondygnacyjny, zaś łączna powierzchnia użytkowa miała wynosić 2685 mkw. Oprócz pomieszczeń przeznaczonych 
Rolę kuratora i autora projektu muzeum albańskiego komunizmu powierzono włoskiemu dziennikarzowi Carlo Bollino ${ }^{24}$. Zespołem odpowiedzialnym za kwerendę kierowała dziennikarka Admirina Peci. Wsparcie instytucjonalne dla realizacji projektu zapewniła organizacja o nazwie Qendra Ura (Centrum Most), która powstała w 2008 r. z inicjatywy grupy artystów, mającej za zadanie tworzenie społeczeństwa solidarnego (shoqeria solidale) przez odwołanie się do potencjału historyczno-artystyczno-kulturowego Albanii. W czasie ceremonii otwarcia obiektu, Bollino podkreślał walor pojednania, mówiąc: „mamy nadzieję, że pomoże on Albańczykom pogodzić się z ich własną historią i ich własną przeszłością”. W opinii kuratora wystawy świadomość tego, czym jest współczesna Albania, powinna kształtować się poprzez poznanie jej korzeni, czemu wystawa miała służyć. Muzeum miało odgrywać nie tylko rolę ekspozycji stałej, ale także miejsca spotkań, wernisaży, koncertów i innych imprez artystycznych.

W przemówieniu wygłoszonym na uroczystości otwarcia premier Edi Rama określił projekt mianem „skarbnicy pamięci zbiorowej”, podkreślając, że „wizyta w nim pozwala zrozumieć komunistyczną przeszłość lepiej, niż potrafią to zrobić wszyscy historycy"25. Podkreślając znaczenie Bunk’Artu w edukacji młodego pokolenia, Rama zwracał uwage na to, że uczenie o komunizmie nie może opierać się na prezentowaniu faktografii, ale odwoływać się do „kreatywnych obrazów” i „,perspektywy przestrzenno-czasowej”. Koncentracja na warstwie wizualnej miała zbliżać albańską ekspozycję do idei muzeum nowoczesnego, w którym wizja artystyczna dominuje nad dokumentacją faktograficzną.

Ekspozycja Bunk’Art składa się z dwóch części, które określane są pojęciami: Ekspozycji Historycznej i Ekspozycji Muzealnej. Pierwsza z nich obejmuje okres okupacji włoskiej i niemieckiej (1939-1944), a także dwie odrębne sale poświęcone pierwszemu okresowi kształtowania ustroju komunistycznego oraz zarysowi dziejów aparatu propagandy i systemu przemocy w latach 1945-1990²6. Ekspozycja określana mianem muzealnej podejmuje próbę odtworzenia autentycznych wnętrz mieszkalnych i pomieszczeń użytkowych znajdujących się w schronie, ale także przedstawia wybrane zagadnienia z dziejów komunistycznego państwa: rozwój edukacji, sportu, a ponadto realizację projektu budowy kilkuset tysięcy bunkrów w Albanii w latach 1971-1985. Szczególne znaczenie w ekspozycji muzealnej odgrywa tzw. Pokój Envera Hodży, który tworzą cztery pomieszczenia (sypialnia, łazienka, gabinet, pokój osobistego sekretarza). Wśród kilku wnętrz mieszkalnych

dla Envera Hodży i jego najbliższych przewidziano także salę, w której na czas zagrożenia mógł obradować albański parlament i centralne władze partii komunistycznej. Oficjalna inauguracja schronu odbyła się 24 czerwca 1978 r., z udziałem Envera Hodży, który potem już nigdy go nie odwiedził. W obiekcie znalazło się 106 pomieszczeń, największe z nich miało pełnić funkcję sali obrad plenarnych parlamentu - Albania opens huge Cold War bunker, https://www.bbc.com/news/world-europe-30160201 [data dost. 2 marca 2019].

${ }^{24}$ Carlo Bollino zaczął karierę dziennikarską, pisząc artykuły o mafii dla włoskiej prasy. Jego związki z Albanią sięgają 1997 r., kiedy rozpoczął współpracę z albańskimi mediami, przejmując wkrótce kierownictwo albańsko-włoskiego dziennika „Gazeta Shqiptare”, a wkrótce potem portalu BalkanWeb. W roku 1999 pracował jako korespondent wojenny w Kosowie i w Macedonii. Powrócił do Albanii w 2014 r., kiedy zakończył współpracę z „Gazetta del Mezzogiorno”. W Tiranie stanął na czele grupy medialnej A1. W roku 2016 uzyskał obywatelstwo albańskie.

${ }^{25} \mathrm{Na}$ podst.: R. Isto, An Itinerary of the Creative Imagination. Bunk'Art and the Politics of Art and Tourism in Remembering Albania's Socialist Past, [w:] Cultures of History Forum (16.05.2017), http://www.cultures-ofhistory.uni-jena.de/politics/albania/an-itinerary-of-the-creative-imagination-bunkart-and-the-politics-of-art-andtourism-in-remembering-albanias-socialist-past/ [data dost. 2 marca 2019].

${ }^{26} \mathrm{Na}$ podst. strony internetowej muzeum - http://bunkart.al/1/ekspozita [data dost. 2 marca 2019]. 
eksponowanych na wystawie tylko pokój przywódcy państwa nosi znamiona przytulnej przestrzeni prywatnej - jest wyposażony w dywany, a jego ściany pokrywa boazeria. $\mathrm{O}$ ile wizyta w Pokoju Hodży rozpoczyna zwiedzanie ekspozycji, to w jej końcowej części umieszczono inscenizację typowego mieszkania w Tiranie z lat 80., a także wnętrze sklepu spożywczego.

Podczas gdy otwarcie pierwszej ekspozycji Bunk'Art nie wywołało zbyt intensywnych reakcji społecznych, to odmienne postawy towarzyszyły uruchomieniu wystawy Bunk'Art 2. Zbudowany w latach 1981-1986 kompleks - oznaczony kryptonimem Obiekt Shtylla - zlokalizowano w podziemnej części dawnego ministerstwa spraw wewnętrznych. Składał się z 24 pomieszczeń, apartamentu dla ministra oraz sali przeznaczonej do celów telekomunikacyjnych ${ }^{27}$. Nowa ekspozycja powstała w sąsiedztwie budynków ministerialnych w centralnej części miasta, która od kilku lat podlegała rewitalizacji, nabierając charakteru strefy spacerowej, niedostępnej dla ruchu kołowego. Projekt realizowano bez konsultacji społecznych, mimo iż został zlokalizowany w historycznej części albańskiej stolicy, stanowiącej do tej pory spójną i nienaruszalną koncepcję architektoniczną (choć sięgającą czasów okupacji włoskiej). Najbardziej kontrowersyjna stała się jednak budowa naziemnego bunkra, wprowadzającego do zasadniczej, podziemnej części ekspozycji. W czasie kiedy prasa albańska pisała o obchodach rocznicy konferencji w Pezie, połączonych z eksponowaniem portretów Envera Hodży, projekt realizowany w centrum Tirany zaczęto postrzegać jako przykład rewitalizacji pamięci o komunizmie. Inicjatorem protestów przeciwko rekomunizacji Albanii stała się Demokratyczna Partia Albanii, której zwolennicy w pierwszym dniu protestów (7 grudnia 2015 r.) próbowali bezskutecznie zniszczyć atrapę bunkra. Od następnego dnia „bunkier” został otoczony przez kordon policjantów, którzy zablokowali dostęp do niego manifestantom, nieukrywającym zamiaru jego zniszczenia. Komentując działania demonstrantów, przywódca DPA Lulzim Basha zachęcał otwarcie do kontynuowania protestów, uznając to za przykład nieposłuszeństwa obywatelskiego ${ }^{28}$.

Oficjalne otwarcie ekspozycji Bunk’Art 2 nastapiło w dniu 16 listopada 2016 r. Uczestniczący w ceremonii premier rządu albańskiego Edi Rama uznał projekt za przykład realizacji misji upamiętnienia i wyrażenia szacunku dla ofiar reżimu komunistycznego. Zasadnicza część ekspozycji została umieszczona w schronie, należącym w przeszłości do ministerstwa spraw wewnętrznych. O ile Bunk'Art 1 koncentrował się na historii armii albańskiej, dość szeroko przedstawiając dzieje państwa i społeczeństwa w okresie komunizmu, o tyle druga odsłona projektu przedstawiała dzieje resortu spraw wewnętrznych i samej policji politycznej, a także omawiała szczegółowo tematykę prześladowań w okresie rządów Envera Hodży. Wejście do ekspozycji stanowi kopuła bunkra-atrapy, którego ściany pokryto fotografiami ofiar reżimu komunistycznego, ich głosy także rozbrzmiewają z głośnika umieszczonego przy wejściu. Ekspozycja Bunk’Art 2 składa się z trzech podstawowych elementów: historii albańskich służb odpowiedzialnych za bezpieczeństwo 2019].

${ }^{27}$ Jw. - http://bunkart.al/2/faqe/ish-bunkeri-antiberthamor-i-ministrise-se-brendshme [data dost. 2 marca

${ }_{28}^{8}$ dhjetori/ Protestë te zyra e Ramës, arkivol te Ministra e Shëndetësisë, „Panorama” 8 XII 2016, http://www. panorama.com.al/8-dhjetori-proteste-te-zyra-e-rames-arkivol-te-ministra-e-shendetesise/ [data dost. 2 marca 2019]; Opening a Museum Commemorating the Victims of a Dictatorship, the Totalitarian Way, 19 XI 2016 , https://exit.al/en/2016/11/19/opening-a-museum-commemorating-the-victims-of-a-dictatorship-the-totalitarianway/ [data dost. 2 marca 2019]. 
publiczne, wybranych aspektów polityki represyjnej z czasów Envera Hodży, a także niewielkiej galerii sztuki posttotalitarnej. Poszczególne sekwencje ekspozycji prezentują dość przypadkową zbieraninę fotografii i artefaktów, pochodzących z różnych okresów dyktatury komunistycznej, uzupełnionych opisami o charakterze encyklopedyczno-słownikowym.

Dwuznaczne stało się w przypadku ekspozycji Bunk’Art 2 aranżowanie sytuacji poznawczej poprzez zastosowane środki artystyczne. O ile projekt w całości koncentruje się na specyfice albańskiej odmiany komunizmu, o tyle dzieła sztuki (instalacje) wykonane przez artystów, którzy generacyjnie związani są z epoką postkomunistyczną (Driant Zeneli, Rubin Beqo, Yllka Gjolesha), skupiają się na uniwersalizmie totalitaryzmu, powielającym schematy znane z innych krajów postkomunistycznych. Sprawia to wrażenie zadania wykonanego na potrzeby ekspozycji, zwiedzanej przede wszystkim przez cudzoziemców, którym owa uniwersalizacja otwiera możliwości kojarzenia doświadczenia albańskiego z innymi przekazami antyautorytarnymi, znanymi z kultury masowej.

Jednym z najsłynniejszych krytyków projektu Bunk’Art stał się mieszkający w Tiranie holenderski artysta i filolog Vincent van Gerven, który jako konsultant recenzował pierwszą wersję projektu. V. van Gerven uznał budowę atrapy bunkra za przykład ,architekturalnej agresji” w historycznej części miasta, wzmacniającej „zabunkrowaną świadomość” Albańczyków. W opinii van Gervena koncepcja wystawy, stworzona przez dziennikarza bez doświadczeń kuratorskich, doprowadziła do powstania dziwacznego połączenia dekoracji i zapisów faktograficznych, którym towarzyszy kakofonia dźwięków, dobiegających z kolejnych pomieszczeń - od hymnu państwowego poprzez syreny alarmowe do sentymentalnych utworów muzycznych. Kuriozalnym elementem ekspozycji stają się diagramy i nieudolny opis 32 tortur, które funkcjonariusze Sigurimi mieli stosować w czasie przesłuchań, przedstawiony w formie atrakcyjnej ciekawostki dla turystów. Kluczowym elementem krytyki van Gerven uczynił deskryptywny charakter tekstów, pozbawionych elementów interpretacyjnych ${ }^{29}$. Bunk'Art 2 staje się w opinii Holendra klasycznym przykładem „fałszywego muzeum” (fake museum), w którym zaprezentowano w większości autentyczne eksponaty, ale zestawione ze sobą w przypadkowy, a często groteskowy sposób $^{30}$. Przykładem groteskowej inscenizacji stał się ,„pokój przesłuchań, w którym umieszczono zestaw mebli biurowych, rozjaśnionych światłem błyskającym w rytmie ludzkiego pulsu. W opinii holenderskiego artysty projekt stanowi przykład nieudolności i marnotrawstwa, a zainteresowanie wystawą staje się wprost proporcjonalne do nieznajomości epoki komunistycznej. Wrażenie chaosu potęguje nadmiar bodźców wizualnych i dźwiękowych, który jednak może budzić zainteresowanie cudzoziemców swoją kuriozalnością.

Oburzony krytyką holenderskiego artysty, głos w obronie projektu zabrał jego twórca - Carlo Bollino. W artykule opublikowanym w grudniu 2016 r. w „Gazeta Shqiptare” Bollino uznał van Gervena za przykład ,berishowskiego analityka”, związanego politycznie z Demokratyczną Partią Albanii i wygłaszającego swoje opinie na zamówienie poli-

\footnotetext{
${ }^{29}$ V. van Gerven Oei, The Unofficial View of Tirana, https://www.berfrois.com/2016/12/vincent-w-j-vangerven-oei-nuclear-attack-on-meaning/ [data dost. 3 marca 2019].

${ }^{30}$ Matilda Terpollari w krytycznej recenzji muzeum zwraca uwagę na jeden z kuriozalnych artefaktów wyeksponowanych w ramach Bunk'Art 2 - koszula wyprodukowana współcześnie przez holenderską C\&A, z widoczną metką, odgrywa rolę elementu stroju więźnia politycznego z czasów Envera Hodży - Eadem, Bunk'Art 2, një memorial antikomunist me rroba gabi, „Panorama” 6 XII 2016, http://www.panorama.com.al/bunkart-2-nje-memorial-antikomunist-me-rroba-gabi/ [data dost. 2 marca 2019].
} 
tyczne. W opinii Bollino błędem jest traktowanie Bunk’Artu wyłącznie jako muzeum, gdyż jest on ,nowoczesną ekspozycją wideo-muzealną, w której historia jest przedstawiana w atrakcyjny, artystyczny sposób". Dowodem na sukces tego przedsięwzięcia miało być kilkadziesiąt tysięcy zwiedzających w ciągu pierwszego roku po otwarciu. Krytyków projektu kurator wystawy oskarżył o próbę „blokady kulturowej”, wynikającej z uprzedzeń i skłonności do tabuizowania przeszłości ${ }^{31}$.

Koncepcja Bunk’Artu nieuchronnie skłania do poszukiwania analogii do innych strategii ekspozycyjnych w placówkach muzealnych Europy Południowo-Wschodniej. Najbardziej oczywiste wydaje się skojarzenie projektu albańskiego z jugosłowiańskim bunkrem atomowym D-0 ARK, wybudowanym w latach 1953-1979 na południe od bośniackiego miasta Konjic, który na wypadek wojny miał stać się schronieniem dla przywódców państwa jugosłowiańskiego. W tym przypadku autentyczność zachowanych wnętrz, w tym także części mieszkalnej przeznaczonej dla Josipa Broz Tity, czyni z ekspozycji swoistą kapsułę czasu, nabierając osobliwego charakteru - jak pisze Magdalena Bogusławska - ,wizualnego zapisu minionego, historycznego wydarzenia o przeszłości, która jednakże pozostała czystą fantazją i nigdy się nie wydarzyła" 32 . W porównaniu z bunkrem D-0 ARK obiekt albański po zniszczeniu oryginalnych wnętrz wiosną 1997 roku traci efekt widmowości i zawieszenia, zauważalny w Konjicu, stając się jedynie mniej czy bardziej udaną próbą rekonstrukcji przestrzeni prywatnej dyktatora.

Jedną z najciekawszych ekspozycji upamiętniających ofiary komunizmu stało się rumuńskie Muzeum Pamięci Ofiar Komunizmu i Oporu Społecznego, otwarte w 1997 r. w dawnym więzieniu w Sighecie ${ }^{33}$. Projekt rumuński eksponuje martyrologię Rumunów i zróżnicowane formy oporu społecznego, uznając naród rumuński za zbiorową ofiarę systemu narzuconego z zewnątrz. Za widoczny przejaw inspiracji rumuńskim muzeum można uznać sekwencję wejściową do ekspozycji Bunk'Art 2, jak również nie do końca udane pomysły inscenizacyjne celi tortur i pokoju przesłuchań. O ile jednak projekt rumuński został zrealizowany w miejscu najbardziej adekwatnym dla upamiętniania ofiar reżimu, o tyle sekwencje cierpień komunistycznych w projekcie albańskim umiejscowiono w obiektach, które w sensie dosłownym nie stały się nigdy obiektami represji i w niewielkim stopniu mogą oddziaływać na emocje zwiedzającego.

Wyeksponowane w ramach ekspozycji Bunk’Art 1 mieszkanie Envera Hodży nasuwa nieuchronnie skojarzenia z Muzeum Socjalizmu, działającym w bułgarskim Prawecu - miej-

\footnotetext{
${ }^{31}$ V. van Gerven Oei, Një përgjigje për Carlo Bollinon nga “bashkëpunëtori hollandez”, 9 XII 2016, https://exit.al/2016/12/20635/ [data dost. 3 marca 2019].

${ }^{32}$ M. Bogusławska, Architektura władzy i artystyczne topografie pamięci (przypadek jugosłowiański), [w:] Czytać, wędrować, być. Tom dedykowany Profesorowi Zdzisławowi Daraszowi, red. M. Bogusławska, J. Goszczyńska, J. Šuler-Galos, Warszawa 2016, s. 223.

${ }^{33}$ Otwarte w 1997 r. muzeum początkowo ograniczało się do pomieszczenia zwanego salą tortur i kilku pustych cel, w których przetrzymywano więźniów politycznych. Od 2004 r. w poszczególnych celach więziennych umieszczono ekspozycje poświęcone kolejnym aspektom kształtowania się i rozwoju państwa komunistycznego, a także poszczególnych form represji. W przypadku niektórych cel, w których więziono znanych przedstawicieli opozycji antykomunistycznej, przywrócono ich oryginalny charakter. Jedną z najważniejszych części ekspozycji stała się zaprojektowana przez Radu Mihailescu Przestrzeń Medytacji i Modlitwy, nawiązująca w formie do katakumb, w których umieszczono nazwiska 8 tysięcy ofiar reżimu - zob. G. Cristea i S. Radu-Bucurenci, Raising the Cross. Exorcising Romania's Communist Past in Museums, Memorials and Monuments, [w:] Past for the Eyes. East European Representations of Communism in Cinema and Museums after 1989, ed. O. Sarkisova i P. Apor, Budapeszt \& N. York 2008, s. 298-300.
} 
scu urodzin Todora Żiwkowa. Nieudana próba stworzenia bułgarskiego muzeum komunizmu w Sofii, Płowdiwie czy Dimitrowgradzie spowodowała, że jego funkcję nolens volens przejął dom należący w przeszłości do przywódcy bułgarskiego państwa komunistycznego, zamieniony na muzeum już w roku $1981^{34}$. Pomimo wzbogacenia oferty muzealnej przez wystawy czasowe obiekt zachował charakter muzeum domowego, odtwarzającego realia życia codziennego Todora Żiwkowa w czasie, kiedy sprawował władzę i regularnie odwiedzał swój dom rodzinny. Również w tym przypadku istotną wartością muzeum w Prawecu jest jego autentyczność, a także aranżacja przestrzeni dostosowana do życzeń jego głównego lokatora. Wystrój Pokoju Envera Hodży zdaje się nawiązywać do wnętrza jego tirańskiej rezydencji, ale niewiele oryginalnych elementów wyposażenia zachowało się z rzeczywistego wnętrza z lat 70.

Spory o komunistyczną przeszłość, które ożywiła dyskusja nad projektem Bunk’Art - rozgrywają się na jednym z frontów toczącej się w tym bałkańskim kraju „wojny o pamięć". O ile jednak polityka rishkrimi e historise otwiera pola konfliktowe z historykami tureckimi, greckimi i serbskimi w ocenie przeszłości osmańskiej i kształtowania albańskiej państwowości, o tyle spory o przeszłość komunistyczną pozostają sporami wewnątrzalbańskimi. Środowiska najbardziej w ten spór zaangażowane - zarówno ofiary systemu, jak i jego beneficjenci, stanowią coraz mniej liczne grupy, a ich przekaz skierowany do społeczeństwa jest coraz mniej czytelny. Z pejzażu Albanii znikają miejsca i obiekty związane z dziedzictwem minionej epoki - taki los spotkał zarówno pomniki identyfikowane z komunizmem, jak też budynki jednoznacznie kojarzone z przeszłością komunistyczną. Symbolicznym przejawem sporów o dekomunizację przestrzeni publicznej stała się w $2011 \mathrm{r}$. propozycja zburzenia Piramidy - planowanej początkowo jako mauzoleum Envera Hodży, która z czasem stała się schronieniem dla instytucji kulturalnych i jednym z najbardziej charakterystycznych symboli albańskiej stolicy. O ile postulaty zburzenia Piramidy można rozpatrywać w kategoriach ideologicznej dekomunizacji, to przebudowę dawnej dzielnicy rządowej (Blloku) czy plany zburzenia Teatru Narodowego można postrzegać głównie jako uwarunkowaną komercyjnie chaotyczną modernizację centrum miasta. Zapomnieniu o komunizmie sprzyja także jego komercjalizacja i banalizacja, której przykładem stały się ekspozycje Bunk'Art 1 i Bunk'Art 2, stanowiące klasyczny przykład nieuporządkowanego i selektywnego przekazu, realizującego bieżące potrzeby polityczne, bez poważnej weryfikacji merytorycznej przez środowisko zawodowych historyków. Projekt Bunk’Art stał się osobliwym przykładem tworzenia „historii bez historyków”, zaś prymat doraźnych celów politycznych i osobliwej estetyki wpisał projekt albański w poetykę kiczu, typową dla przebudowy Tirany w okresie rządów Ediego Ramy, porównywalnego, jak pisze Fatos Lubonja, z macedońskim projektem Skopje $2014^{35}$.

Paradoks albańskiej (nie)pamięci o komunizmie staje się dla postronnych obserwatorów wypadkową dwóch czynników: przekonania o wyjątkowości systemu komunistycz-

\footnotetext{
${ }^{34}$ Muzeum poświęcone początkowo postaci Todora Żiwkowa i jego wkładowi w rozwój komunistycznej Bułgarii funkcjonowało nieprzerwanie do roku 1989. Po kilku latach przerwy, na życzenie lokalnej społeczności obiekt uruchomiono ponownie. Miejsce stałej ekspozycji upamiętniającej Żiwkowa zajęły wystawy czasowe, omawiające w sposób krytyczny wybrane aspekty bułgarskiego komunizmu - N. Vukov, The "Unmemorable" and the "Unforgettable" "Museumizing" the Socialist Past in Post-1989 Bulgaria, [w:] Past for the Eyes..., s. $307-313$.

${ }^{35}$ F. Lubonja, Kitschi i Ramës si variant $i$ kitschit të Gruevskit, „Panorama” 15 VII 2018, http://www.panorama. com.al/kitschi-i-rames-si-variant-i-kitschit-te-gruevskit/ [data dost. 2 marca 2019].
} 
nego w Albanii (w przekonaniu większości świadków epoki), a także ucieczki od komunizmu jako doświadczenia społecznego o znikomej wartości, służącego jedynie celom politycznym, czy nawet partyjnym.

Współczesne badania nad polityką pamięci zwracają uwagę na zjawisko zwane ideologią pamięci, kiedy określona wizja przeszłości zostaje uwikłana w grę interesów podmiotów aktywnych w życiu politycznym ${ }^{36}$. Projekt stworzony przez włoskiego dziennikarza nie tylko ignoruje albańskie tradycje wystawiennicze czy doświadczenia bałkańskich muzeów komunizmu, ale także pogłębia stereotypowe schematy postrzegania postkomunistycznej Albanii przez Włochów, przypominając jako żywo obraz Albanii utrwalony we włoskim filmie Lamerica z 1994 roku (reż. Gianni Amelio). Aktywny udział premiera Ediego Ramy w promocji projektu wskazuje na istotną rolę, jaką odgrywają tego rodzaju ekspozycje w próbach budowania wizerunku nowoczesnego przywódcy politycznego, który pragnie być postrzegany przez zagraniczne media jako niezależny i ekstrawagancki intelektualista, łącząc atrakcyjne medialnie cechy buntownika i nonkonformisty ${ }^{37}$. Przebudowa Tirany, którą rozpoczął w czasach, kiedy pełnił funkcję burmistrza (2000-2011), ukształtowała wizerunek albańskiego przywódcy, łączącego artystyczne pasje z polityczną charyzmą ${ }^{38}$. Niemniej strategię polityczną Ramy należy postrzegać także w perspektywie stabilokracji - pojęcia wykorzystywanego w ostatnich latach na określenie systemu sprawowania władzy w postkomunistycznych państwach bałkańskich ${ }^{39}$. Stabilokracja - postrzegana najczęściej z perspektywy zawłaszczania przez ekipę rządzącą przestrzeni medialnej i redukcji możliwości swobodnej wypowiedzi, niezgodnej z narracją urzędową może stać się (i w przypadku albańskim niewątpliwie się staje) odgórnym projektem kształtowania własnej, atrakcyjnej komercyjnie narracji o przeszłości.

\section{Bibliografia}

8 dhjetori/ Protestë te zyra e Ramës, arkivol te Ministra e Shëndetësisë, „Panorama” 8 XII 2016, http:// www.panorama.com.al/8-dhjetori-proteste-te-zyra-e-rames-arkivol-te-ministra-e-shendetesise/ [data dost. 2 marca 2019].

Abrahams F. C., Modern Albania. From Dictatorship to Democracy in Europe, New York \& London 2015.

Agron Tufa tregon kërcënimet: Pse duhen ndaluar filmat e komunizmit, rozm. A. Mille, „Panorama” 15 III 2017, http://www.panorama.com.al/agron-tufa-tregon-kercenimet-pse-duhet-te-ndalohenfilmat-e-komunizmit/ [data dost. 2 marca 2019].

Albania opens huge Cold War bunker, https://www.bbc.com/news/world-europe-30160201 [data dost. 2 marca 2019].

${ }^{36}$ R. Chwedoruk, Polityka historyczna, Warszawa 2018, s. 242-243.

${ }^{37}$ B. Budini, Yll i partisë, yll i mediave: Rasti i ngritjes mediatike të Edi Ramës, „Polis” 2012/1, s. 85-94.

${ }^{38} \mathrm{~B}$. Budini kojarzy specyfikę działalności politycznej E. Ramy z pojęciem „,elebrity politics”, podkreślając znaczenie udziału tego polityka w skoncentrowanych na jego osobie spektaklach publicznych - Eadem, „Ringjallja e autorit” përmes vetë-stilizimit; rasti i kryeministrit Rama, „Polis” 2016/1, s. 27.

${ }^{39}$ Florian Bieber definiuje stabilokracje jako system polityczny oparty na nieformalnych, klientelistycznych strukturach władzy, kontroli przestrzeni medialnej i generowaniu kryzysów służących podważeniu społecznego zaufania do demokracji i rządów prawa, a jednocześnie akceptowany przez Unię Europejską w interesie stabilizacji regionu - Idem, The Rise (and Fall) of Balkan Stabilitocracies, https://www.cirsd.org/en/horizons/horizonswinter-2018-issue-no-10/the-rise-and-fall-of-balkan-stabilitocracies (data dost. 2 marca 2019 r.). 
Apor P., Museums of cilivization, museums of state, museums of identity; national museums in Europe, 1918-2000, [w:] National Museums and Nation-Bulding in Europe 1750-2010. Mobilization and Legitimacy, Continuity and Change, ed. P. Aronsson i G. Elgenius, Routledge 2015.

Austin R. C., Transitional Justice as Electoral Politics, [w:] Post-Communist Transitional Justice. Lessons from Twenty-Five Years of Experience, ed. L. Stan, N. Nedelsky, Cambridge University Press 2015.

Bogusławska M., Architektura władzy i artystyczne topografie pamięci (przypadek jugosłowiański), [w:] Czytać, wędrować, być. Tom dedykowany Profesorowi Zdzisławowi Daraszowi, red. M. Bogusławska, J. Goszczyńska, J. Šuler-Galos, Warszawa 2016.

Brunnbauer U., Introduction, [w:] (Re)Writing History: Historiography in Southeast Europe after Socialism, ed. Idem, Münster 2004, s. 9-30.

Budini B., ,Ringjallja e autorit” përmes vetë-stilizimit; rasti i kryeministrit Rama, „Polis” 2016/1, s. 26-35.

Budini B., Yll i partisë, yll i mediave: Rasti i ngritjes mediatike të Edi Ramës, „Polis” 2012/1, s. $85-94$.

Bieber F., The Rise (and Fall) of Balkan Stabilitocracies, https://www.cirsd.org/en/horizons/horizonswinter-2018-issue-no-10/the-rise-and-fall-of-balkan-stabilitocracies (data dost. 2 marca 2019 r.).

Chwedoruk R., Polityka historyczna, Warszawa 2018.

Czekalski T., (Nie)pamięć o komunizmie. Przypadek albański, „Rocznik Antropologii Historii” 2012, nr 1-2, s.163-174.

Elbasani A. i Lipiński A., Transitional Justice in Albania: Historical Burden, Weak Civil Society and Conflicting Interests, [w:] Transitional Justice and Civil Society in the Balkans, ed. O. Simić, Z. Volčič, New York 2013.

Gerven van Oei V., Një përgjigje për Carlo Bollinon nga “bashkëpunëtori hollandez”, 9 XII 2016, https://exit.al/2016/12/20635/ [data dost. 3 marca 2019].

Gerven van Oei V., The Unofficial View of Tirana, https://www.berfrois.com/2016/12/vincent-w-jvan-gerven-oei-nuclear-attack-on-meaning/ [data dost. 3 marca 2019].

Giakoumis K., Pragmatist Politics on Memory and Oblivion. Post-Communist Attitudes towards Communist Museology in Albania, [w:] Between Apathy and Nostalgia. Public and Private Recollections of Communism in Contemporary Albania, ed. J. Godole, I. Idrizi, Tirana 2019, s. $46-59$.

Gołek-Sepetliewa D., Dychotomia pamięci w postkomunistycznej Bułgarii, „Acta Baltico-Slavica” 42: 2018, s. 25-38.

Grgic A., Deviating memories: Armando Lulaj's seriously playful excursions into Albania's history, „Images” vol. XXIII, nr. 32 (2018), s.50.

Isto R., An Itinerary of the Creative Imagination. Bunk'Art and the Politics of Art. and Tourism in Remembering Albania's Socialist Past, [w:] Cultures of History Forum (16.05.2017), http://www. cultures-of-history.uni-jena.de/politics/albania/an-itinerary-of-the-creative-imagination-bunkartand-the-politics-of-art-and-tourism-in-remembering-albanias-socialist-past/ [data dost. 2 marca 2019].

Isto R., The Monument as Ruin: Natality, Spectrality, and the History of the Image in the Tirana Independence Monument, „Sic: časopis za književnost, kulturu i književno prevođenje” 2006/2, s. $1-31$.

Konferenca Shkencore për 70-Vjetorin e Çlirimit, https://arsimi.gov.al/konferencja-shkencore-per70-vjetorin-e-clirimit/ [data dost. 5 marca 2019].

Lubonja F., Albania - wolność zagrożona. Wybór publicystyki z lat 1991-2002, tł. D. Horodyska, Sejny 2005. 
Lubonja F., Kitschi i Ramës si variant i kitschit të Gruevskit, „Panorama” 15 VII 2018, http://www.panorama.com.al/kitschi-i-rames-si-variant-i-kitschit-te-gruevskit/ [data dost. 2 marca 2019].

Lubonja F., Ramiz Alia eshte midis nesh, „Panorama” 14 października 2011, http://www.panorama. com.al/ramiz-alia-eshte-midis-nesh/ [data dost. 2 marca 2019].

Opening a Museum Commemorating the Victims of a Dictatorship, the Totalitarian Way, 19 XI 2016, https://exit.al/en/2016/11/19/opening-a-museum-commemorating-the-victims-of-a-dictatorshipthe-totalitarian-way/ [data dost. 2 marca 2019].

Past for the Eyes. East European Representations of Communism in Cinema and Museums after 1989, ed. O. Sarkisova i P. Apor, Budapest \& N. York 2008.

Terpollari M., Bunk'Art 2, një memorial antikomunist me rroba gabi, „Panorama” 6 XII 2016, http://www. panorama.com.al/bunkart-2-nje-memorial-antikomunist-me-rroba-gabi/ [data dost. 2 marca 2019].

Tadeusz Czekalski, dr hab., profesor w Zakładzie Antropologii Historycznej w Instytucie Historii Uniwersytetu Jagiellońskiego; zajmuje się m.in. historią społeczną Bałkanów w XIX-XX w., historią Albanii w XIX-XX w. oraz historią europejskiej kultury kulinarnej. Ważniejsze publikacje: Pogrobowcy Wielkiej Idei. Przemiany społeczne w Grecji w latach 1923-1940 (Kraków 2007); Historia Albanii (Wrocław 2009, współautor), The Shining Beacon of Socialism in Europe (Kraków 2013).

e-mail: tadeusz.czekalski@uj.edu.pl

ORCID: 0000-0002-8494-1769 